\title{
Vote-buying as a moderator variable: The effect of political trust on college student participation in election
}

\section{Pembelian suara sebagai variabel moderator: Pengaruh kepercayaan politik terhadap partisipasi mahasiswa dalam pemilihan umum}

\section{Arief Sumantri* \& Suryanto}

Department of Personality and Social Psychology, Faculty of Psychology, Universitas Airlangga Address: Jalan Dharmawangsa Dalam, Airlangga, Surabaya, East Java 60286 E-mail: aripsumantri143@gmail.com*\& suryanto@psikologi.unair.ac.id

Article History: Received 6 February 2019; Accepted 4 August 2020; Published Online 14 September 2020

\begin{abstract}
Considering that the number of college student beginner voters in the Indonesian 2019 General Election has experienced a drastic increase, this research aims to determine the effect of political trust and vote-buying on college students' political participation in the general elections, partially, and simultaneously. This research was conducted on 348 active college students in Surabaya, using the purposive sampling technique. The scale was used to measure political participation, vote-buying, and political trust was composed itself by the researchers. The data analysis techniques used to test the research hypotheses were the Hierarchical Regression Test, Moderated Regression Analysis (MRA), and the Andrew Hayes Process. The results of the analysis show that political trust $(\mathrm{p}=0.038)$, vote-buying $(\mathrm{p}=0.001)$ partially, and simultaneously $(\mathrm{p}=0.000)$ affect political participation. Partially, political trust has a positive effect, while on the other hand, vote-buying has a negative effect. In addition, vote-buying is also a significant moderator variable used to strengthen the influence of political trust $(\beta=0.658, \mathrm{t}=1.984, \mathrm{p}=0.048)$ among college students concerning political participation. In this study, vote-buying acts as a quasi-moderator because the effect of $Z$ (vote buying) on $Y$ (political participation) and the effect of $Z * X 1$ (vote-buying*political trust) interaction on $Y$; has been proven to be significant. It can be concluded that political trust positively and significantly influences college students' political participation in the general elections.
\end{abstract}

Keywords: political trust; vote-buying; political participation; college students

\begin{abstract}
Abstrak
Mengingat jumlah suara mahasiswa sebagai pemilih pemula pada Pemilihan Umum (Pemilu) 2019 mengalami peningkatan drastis; penelitian ini bertujuan untuk mengetahui pengaruh dari kepercayaan politik dan pembelian suara terhadap partisipasi politik mahasiswa dalam pemilihan umum, baik secara parsial maupun simultan. Kemudian, pengaruh dari kepercayaan politik terhadap partisipasi politik mahasiswa dengan pembelian suara sebagai variabel moderator. Penelitian ini melibatkan 348 mahasiswa berstatus aktif yang berada di Surabaya, dengan menggunakan teknik purposive sampling. Skala yang digunakan untuk mengukur partisipasi politik, kepercayaan politik, dan pembelian suara dikonstruksi sendiri oleh peneliti. Teknik analisis data untuk menguji hipotesis menggunakan Hierarchical Regression Test, Moderated Regression Analysis (MRA) dan Andrew Hayes Process. Hasil analisis menunjukkan kepercayaan politik $(p=0.038)$ dan pembelian suara $(p=0.001)$ berpengaruh baik secara parsial, maupun simultan $(p=0.000)$ terhadap partisipasi politik. Secara parsial, kepercayaan politik berpengaruh positif, sedangkan pembelian suara berpengaruh negatif. Selain itu, pembelian suara juga secara signifikan menjadi variabel moderator yang memperkuat pengaruh kepercayaan politik $(\beta=0,658, t=1,984, p=0,048)$ terhadap partisipasi politik mahasiswa. Pembelian suara dalam penelitian ini berperan sebagai quasi-moderator, karena pengaruh $Z$ (pembelian suara) terhadap $Y$ (partisipasi politik) dan pengaruh interaksi $Z * X 1$ (pembelian suara*kepercayaan politik) terhadap Y; keduanya terbukti signifikan. Dapat disimpulkan bahwa kepercayaan politik berpengaruh positif dan signifikan terhadap partisipasi politik mahasiswa dalam pemilihan umum.
\end{abstract}

Kata kunci: kepercayaan politik; pembelian suara; partisipasi politik; mahasiswa 


\section{Introduction}

In terms of vote acquisition, beginner voters in Indonesia are voters who have a high potential to gain votes in the general elections. Komisi Pemilihan Umum (2014) showed that the number of beginner voters was around 27 million out of a total of 147 million voters (Putra et al. 2014). In the 2009 general elections, there were approximately 36 million voters out of 171 million, moreover, the number of voters aged 17 to 20 years old in the 2014 general elections was around 14 million, while those aged 20 to 30 years old totaled around 45.5 million. Badan Pusat Statistik (2010) population census, the number of people aged 15 to 19 years old amounted to 20.880 .734 people consisting of 10.614 .306 men and 10.266.428 women. On the other hand, those aged 20 to 24 years old, totaled 19.891.633 million people consisting of 9.887.713 men and 10.003.920 women, and if these numbers are added up, the total will be 40.772 .367 . In general, it is assumed that the beginner voters and young voters knew as college students will increase in the 2019 general elections.

Various studies, including those conducted in Indonesia, have shown a direct relationship between political trust and political participation. Political trust influences the emergence of political participation in social movements (Matulessy \& Samsul 2013). Wahyudi et al. (2013) showed a positive relationship between political trust paired with the satisfaction of democracy and the level of political participation. Masturah (2014) also pointed out that trust in the presidential candidates influences novice voters' political participation. Handaningrum \& Rini (2014) found that political trust is relatively low; however, political participation is relatively high. El Sahn et al. (2013) assumed a positive effect from engagement responses on interpersonal groups, voting disadvantages, voting usefulness, mass media, party differences, party identification, political trust, and political efficacy. There was also found to be a negative influence from political systems on the intention to choose someone in the general election. Studies such as those by Goeddeke (2004), Yao \& Murphy (2007), Carter \& Campbell (2011) proved that there is a positive relationship between public trust and political participation in the general election. Based on Ondercin \& White (2011), there is a relationship between trust in a particular candidate and the candidate's level of knowledge. It is a guideline for someone to consider concerning their active involvement in political activity. Dermody $\&$ Scullion (2008) also reached the same conclusion, specifically that the candidates' trust has an impact on the attitude and political participation of novice voters.

In general, political participation occurs not only because of the interest of an individual or a group independently; however also because of other people who ask or even force particular individuals or groups to vote. It is known as the mobilization of political participation (Gaffar 1998). In the mobilization stage, there is a factor that influences political participation, namely vote-buying. In the Indonesian general election, it is known as money politics. Schaffer \& Schedler (2007) said that in vote-buying, various types of material are often exchanged for voters' political support regarding their political participation. In addition to cash and services, the materials can be in soap, chairs, gloves, watches, cement, alcohol, coffee, sugar, instant noodles, cigarettes, shirts, mobile phones, fans, cooking oil, and rice. Bratton (2008), in Nigeria found that the forms of vote-buying generally offered to the voters are cash (68\%), clothing and food commodities $(26 \%)$, and job opportunities $(6 \%)$.

Research regarding vote-buying and political participation conducted by Nurdin (2014) revealed that, money politics (vote-buying) has a significant effect on voting behavior. Nurdin (2014) also emphasized that money politics is unrelated to voting behavior, either sociologically, sociopsychologically, or rationally. Instead, it is influenced by the competition between candidates, the candidates' materials capability, political tradition, supervision, and law enforcement, the latter of which can be relatively weak. Zetra et al. (2015), who examined political participation and votebuying or money politics, pointed out that the most common type of money politics is the provision of food, clothing, and money, where the giving of money or goods is often done at the time of the campaign and partly in the morning before the vote. It is reported that more than half of their respondents (69.6\%) engaged in money politics (vote-buying). Komisi Pemilihan Umum (2015) also assessed the influence of money politics on political participation. Their study showed that money politics does not affect voter participation; however, it is interesting to find that most of the respondents want there to be money politics involved in general elections. 
Money politics is a typical term used in the political culture of general elections in Indonesia. The term describes the political phenomenon of using the influence of money power (in the 'negative' sense) during the election process. For other countries outside of Indonesia, money politics is a new term in political literature (Zetra et al. 2015). In Western political science, the concept that is often used to explain money politics in the Indonesian general election is vote-buying. It should be noted that vote-buying in various countries has various meanings, and it is often understood in different contexts depending on the cultural factors, political traditions, and the election model applied (Schaffer \& Schedler 2007). In the Indonesian general election culture, vote-buying starts from the presidential and legislative elections up to the level of the village head election. Kana (2001) pointed out that money politics is typical in the village head election where people often see it as a symbol of "tali asih," (can be described as a form of care or appreciation from the party concerned to the community). Komisi Pemilihan Umum (2014) revealed that democracy at a fundamental level (village head election) is full of money politics because it is considered something familiar. People are not sensitive to the dangers because they do not feel that vote-buying is a behavior that must be avoided normatively, it shows a lack of public knowledge about politics.

Electoral politics have realized the potential of the voices of beginner voters who come in large numbers in college. One political party has opened up its registration for the 2019 legislative candidates, and it has even given the opportunity, not only to its cadres, however also to the public, including youths and college students (Tashandra 2017). It shows that college student involvement has been taken into account in the world of electoral politics. It is interesting to observe that many college students who are part of the political party campaign group are willing to bring their attributes as college students to support the candidates. In 2014, around 1.000 college students gathered at Hotel Indonesia in Jakarta to declare themselves as the team of one of the candidates (Detik News 2014). In other areas, one network of college students also participated in the declaration to support (Habibi 2014).

In addition to political participation and political trust, the researcher's primary concern is the trend of vote-buying in the general elections. It is known as money politics in the culture of the Indonesian general elections. The main target of vote-buying is to gain the sympathy and trust of the voters. College students expect to be the pioneers and agents of change on the frontlines in nation-building. College students must act as smart voters and keep the electoral process honest, fair, direct, public, free, and confidential. It will generate a leader that is reliable for the community. The General Elections Commission or Komisi Pemilihan Umum (KPU) also expects the college students' role to include watching the electoral process and reducing the number of abstentions (Berita Satu 2013). According to Santrock (2011), beginner voters and young voters are classified as being in the category of early adulthood. Santrock (2011) divided early adulthood into 18-25 years old, continuing up until 30 years old. As can be seen from the intellectual transition, categorized this stage as the phase of operational formal, which can even progress to the point of entering the phase of post-operational formal in terms of cognitive development (Santrock 2011). It means that this group already engages in an intricate pattern of thought as they can think abstractly, logically, and rationally. Through the perspective of social psychology, vote-buying can be assumed to be a reward for either the offender or recipient. In other words, vote-buying can strengthen trust in political participation, on the contrary, it can also weaken it.

In the present study, the researcher further addressed whether there is an effect from political trust and vote-buying on the political participation of college students in the general elections, both simultaneously (H1) and partially (H2). Therefore, the moderating effect of vote-buying (H3) on the effect of political trust on the college students' political participation is essential.

\section{Research Method}

The researchers constructed the measurement of the variables of political participation $(\alpha=652)$, political trust $(\alpha=957)$, and vote-buying $(\alpha=851)$. The researchers in this study used construct validity and content validity. The main focus was to construct the content of each measuring instrument to reflect the conceptual definition. Content validity was fulfilled by conducting a consultation with 
experts (minimum three) in order to get responses and suggestions along with any changes in the questionnaire that have been made. The experts in question were the supervisors of the study and associated experts in the field. The instrument's testing was then conducted in Kendari, Southeast Sulawesi Province, from $28^{\text {th }}$ to $30^{\text {th }}$ June 2018. After the tryout, a validity and reliability test was performed to fulfill the construct's validity. The measurement tool for political participation was constructed using the aspects of political participation by Cottam et al. (2012) which consisted of personal knowledge, knowledge that is known through the mass media, worry, and enthusiasm. Political trust examines using the trust dimensions (Lewicki \& Bunker 1995). It was widely used to measure political trust (Masturah 2014, Rini 2016), including ability, integrity, and benevolence. The vote-buying variable was assessed using the indicators from the research by the KPU in 2015 .

The population in this study consisted of active college students in both State and Private Universities in Surabaya, totaling 171.974 people based on the data in 2016/2017 from each University contained in the database of the Ministry of Research, Technology, and Higher Education (Pangkalan Data Pendidikan Tinggi 2018). Based on the table guidelines Sugiyono (2010), 348 college students were determined to be the research samples with a significance or error rate of $5 \%$ and a confidence level of $95 \%$. The sampling was carried out using purposive sampling, and all of the respondents in this study (Table 1) reached the compulsory age for voting and had the status of beginner voters ranging in age from 17-25 years old $(\mathrm{M}=20.16, \mathrm{SD}=2.126)$. Novice voters, who are generally college students, were selected as participants because there was an increase in voters' number in the 2019 general election (Badan Pusat Statistik 2010). Nowadays, political parties are increasingly aware of the potential of novice voters (college students). It can be seen from one political party, allowing college students to register as candidates for the 2019 legislative election (Tashandra 2017). This research was conducted at the end of 2018 ahead of the 2019 general election in Indonesia. This study's data analysis was done using the Hierarchical Regression Test, Moderated Regression Analysis (MRA), and the Andrew Hayes Process using the SPSS 25 windows program to test the hypotheses.

\section{Results and Discussion}

Political participation (Table 3 ) correlates with vote-buying $(\mathrm{p}=0.001)$ and political trust $(\mathrm{p}=0.038)$. Vote buying is related to political trust $(\mathrm{p}=0.001)$. Besides that, it is known that age also correlates with political trust $(\mathrm{p}=0.005)$. Simultaneously, the regression model (Table 4) showed significant results $(\mathrm{F}=9.509, \mathrm{p}<.01, \mathrm{R} 2=.052)$. There is a partial positive relationship between the variables of political trust and the political participation variable $(\mathrm{B}=.037, \mathrm{t}=2.75, \mathrm{p}<.01, \mathrm{R} 2=.012)$. The votebuying variable shows a negative relationship with political participation $(B=-.090, t=-3.81, p<.01$, $\mathrm{R} 2=.031$ ). Overall, the regression model shows that $\mathrm{H} 1$ and $\mathrm{H} 2$ are accepted.

Table 1.

Demographic characteristics of the participants

\begin{tabular}{lccccccc}
\hline \multirow{2}{*}{ Gender } & \multicolumn{3}{c}{$\mathbf{N}$} & \multicolumn{3}{c}{ Age range } & \multicolumn{2}{c}{ Education (on going) } \\
\cline { 2 - 8 } & Frequency & $\begin{array}{c}\text { Percentage } \\
(\%)\end{array}$ & $\mathbf{1 7 - 1 9}$ & $\mathbf{2 0 - 2 2}$ & $\mathbf{2 3 - 2 5}$ & $\begin{array}{c}\text { Bachelor's } \\
\text { program }\end{array}$ & $\begin{array}{c}\text { Master's } \\
\text { program }\end{array}$ \\
\hline Male & 191 & 29 & 36 & 44 & 21 & 90 & 11 \\
Female & 247 & 71 & 110 & 107 & 30 & 229 & 19 \\
\hline Total & $\mathbf{3 4 8}$ & $\mathbf{1 0 0}$ & $\mathbf{1 4 6}$ & $\mathbf{1 5 1}$ & $\mathbf{5 1}$ & $\mathbf{3 1 8}$ & $\mathbf{3 0}$ \\
\hline \multicolumn{7}{c}{ Source: Primary data (2018) }
\end{tabular}

The results from the regression statistical test show there to be a unidirectional relationship between political trust and political participation among college students. This emphasizes that if political trust is improved, then the level of political participation will also increase. The results of this study are in line with the research by Dermody et al. (2010) where political trust affected $51 \%$ of the voters' behavior. Grönlund \& Setälä (2007) also found there to be a positive relationship between trust and the decision to vote in the general election. According to Wahyudi et al. (2013), there was a positive relationship between political trust and democratic satisfaction in relation to the level 
of political participation among the college students. Masturah (2014) added that in the context of the presidential elections, the trustworthiness of the presidential candidates affects the political participation of the beginner voters. Based on the categorization of political trust in relation to the subject of the study (Table 2), out of a total of 348 college students, there were 189 college students $(54.3 \%)$ who had a low level of political trust while the other 159 college students $(45.7 \%)$ claimed to have a high level of political trust.

In the political context, political trust is one's trust in the current political components (Misztal 2001). It is not just an assessment of policy, it also involves the perception of the information and emotional support of the government (Zhang \& Wang 2010). Political trust is the hope of the community for a leader to be able to respond, aggregate, and articulate people's demands and aspirations (Akhrani 2016). One factor that influences this political trust is the high level of trust in the government (Schiffman et al. 2010). Surbakti (1999) said that political awareness and political trust are the psychological variables that influence political participation. Cholisin \& Nasiwan (2012) also proposed that someone with a high level of political awareness and trust in the government will tend to be active in terms of political participation.

Table 2.

Variable categorization

\begin{tabular}{lcc}
\hline \multicolumn{1}{c}{ Variables } & Frequency (N) & Percentage (\%) \\
\hline Political participation & & \\
High & 169 & 48.6 \\
Low & 179 & 51.4 \\
Total & 348 & 100 \\
Political trust & & \\
High & 159 & 45.7 \\
Low & 189 & 54.3 \\
Total & 348 & 100 \\
Vote buying & & \\
High & 183 & 52.6 \\
Low & 165 & 47.4 \\
Total & 348 & 100 \\
\hline \multicolumn{2}{l}{}
\end{tabular}

Source: Primary data (2018)

On the one hand, Lewicki \& Bunker (1995), Mayer et al. (1995) revealed there to be three dimensions contained in trust, namely ability (related to a performance trigger is based on knowledge and competencies), integrity (related to the consistency between principles and actions), and benevolence (related to the positive behavior shown in and to the public). Misztal (2001) argued that trust is closely related to the concepts of social capital, civil society, and social cooperation. The political trust in the government is determined by the alignment of the policies of the government with the expectations of society at large (Zhang \& Wang 2010). The capital elements that shape the social capital (Putnam et al.1993) are participation in a network, reciprocity, trust, social norms, values, and active acts. Putnam (1995), who examined a case in the United States, showed that low level political participation, weakened interpersonal trust levels and decreased levels of sociability in sociopolitical life were present. These are the indicators of a decline in the availability of social capital in the administration of democratic life in the United States. Therefore social capital in a democratic country is very important. Politics is closely associated with social capital because politics cannot be separated from the social world (Schyns \& Koop 2010).

The statistical regression test results (Table 4) indicate an inverse relationship between vote-buying and political participation in college students; in other words, when vote-buying increases, the level of political participation decrease. It means that vote-buying will reduce the political participation of 
college students. Significantly, concerning different research subjects, Nurdin (2014), which found that the practice of money politics (vote-buying) has a significant effect on voting behavior. Zetra et al. (2015) also examined political participation and vote-buying (money politics). They wrote that the most common type of money politics was the provision of assistance in the form of food and clothing and money (Nurdin 2014, Zetra et al. 2015). It was often carried out during the campaign and ahead of the election event.

Table 3.

Descriptive statistics and the Pearson $r$ correlation

\begin{tabular}{|c|c|c|c|c|c|c|}
\hline Variable & 1 & 2 & 3 & 4 & 5 & 6 \\
\hline Political participation & - & & & & & \\
\hline Vote buying & $-0.177^{\star *}$ & - & & & & \\
\hline Political trust & $0.111^{*}$ & $0.176^{*}$ & - & & & \\
\hline Gender & 0.021 & 0.084 & 0.002 & - & & \\
\hline Age & -0.021 & -0.065 & $-0.149^{* *}$ & 0.092 & - & \\
\hline Education & 0.045 & -0.055 & -0.077 & 0.052 & $0.541^{* *}$ & - \\
\hline Mean & 37.45 & 36.98 & 55.45 & 1.29 & 20.16 & 1.09 \\
\hline Standard Deviation & 3.36 & 7.56 & 13.50 & 0.45 & 2.12 & 0.28 \\
\hline
\end{tabular}

Table 4.

Results of the hierarchical regression test

\begin{tabular}{lcccccccc}
\hline & \multicolumn{3}{c}{ Block 1 } & \multicolumn{6}{c}{ Block 2 } \\
\cline { 2 - 9 } & $\begin{array}{c}\text { Political } \\
\text { trust } \\
\beta\end{array}$ & $\mathrm{R}^{2}$ & $\begin{array}{c}\text { Vote } \\
\text { buying } \\
\mathrm{B}\end{array}$ & $\begin{array}{c}\mathrm{R}^{2} \\
\text { Change }\end{array}$ & $\mathrm{R}^{2}$ & $\begin{array}{c}\text { Adjusted } \\
\mathrm{R}^{2}\end{array}$ & $\begin{array}{c}\text { ANOVA } \\
\text { result (F) }\end{array}$ & Sig. F \\
\hline Political participation & .147 & .012 & -.203 & .040 & .052 & .047 & 9.509 & .000 \\
\hline
\end{tabular}

Source: Primary data (2018)

Based on the research respondents' categorization (Table 2), out of 348 college students, 183 college students $(52.6 \%)$ have a high interest in vote-buying. It suggests that the votes of those 183 college students can be bought in the general elections. It is assumed that money politics (vote-buying) occurs because most voters prefer money or other material things rather than paying attention to other indicators such as the candidates' credibility, personality, and experience in the political realm (Nurdin 2014). Nurdin (2014), where more than half of the respondents (69.6\%) admitted to accepting money politics. In vote-buying, many different material types are usually exchanged with voters' political support regarding their political participation in elections. Besides money and services, it can be in the form of soap, chairs, sarongs, watches, cement, whiskey, coffee, sugar, instant noodles, cigarettes, shirts, mobile phones, fans, cooking oil, and rice (Schaffer \& Schedler 2007). Three views can be elaborated on in terms of the relationship between vote-buying and voting behavior (Nurdin 2011).

First, the view that money politics has a significant influence on voting behavior such as in the research conducted by Bratton (2008) in Nigeria and Kenya is where the practice of vote-buying has more influence on people with less education than those with a higher level of education. Second, the assumption that money politics does not significantly influence voting behavior such as the research by Vicente \& Wantchekon (2009) in West Africa is where voting does not have an effect even among the poor voters in areas where economic development is relatively low. In that study, political education was considered a determining factor for money politics' effectiveness in influencing voter preferences. Third, the perspective that the voters' response to money politics in 
each layer of society can vary depending on each society's social, economic, and cultural conditions. Schaffer \& Schedler (2002), explained "vote buying carries different meanings in different historical and cultural contexts." For example, in Taiwan, it was found that guests have the habit of giving a small gift to their host (Rigger 1994, Nurdin 2011). Muhtadi (2018), showed that vote-buying in Indonesia is more concentrated before or during the election day and sometimes before dawn. In Indonesia, this phenomenon is known as "Serangan Fajar." Based on Table 5, it can be concluded that the variable of vote-buying strengthens (positive effect) the effect of political trust on political participation $(p=.048<.050)$.

Table 5.

Results of the Moderated Regression Analysis (MRA)

\begin{tabular}{cccccc}
\hline Model & B & Std. Error & B & T & Sig. \\
\hline Interaction political trust x vote buying & .003 & .002 & .658 & 1.984 & .048 \\
\hline $\begin{array}{c}\text { Dependent variable: Political Participation } \\
\text { Source: Primary data (2018) }\end{array}$ & & &
\end{tabular}

The slope for political trust (Figure 1) predicts political participation at each level of vote-buying. For low vote buying, political trust $b=0.01, t(344)=0.92, p=0.35$. It means that for low vote-buying, there is no relationship between political trust and political participation. The average between votebuying and political trust $\mathrm{b}=0.03, \mathrm{t}(344)=2.96, \mathrm{p}=0.00$ shows that on average, the political trust gives us 0.03 points for the final political participation. For a high level of vote-buying, political trust $\mathrm{b}=0.06, \mathrm{t}(344)=3.35, \mathrm{p}=0.00$. On average, for vote-buying, the political trust gives us 0.06 points for the final political participation. The conclusion from the Moderated Regression Analysis (MRA) and the Andrew Hayes Model 1 Process tests also proves the third hypothesis (H3) in this study. In the first hypothesis test, variable $\mathrm{Z}$ (vote-buying) and the $\mathrm{Z} * \mathrm{X} 1$ interaction have a significant effect on variable $Y$ (political participation), vote-buying is included in the quasi-moderator criteria.

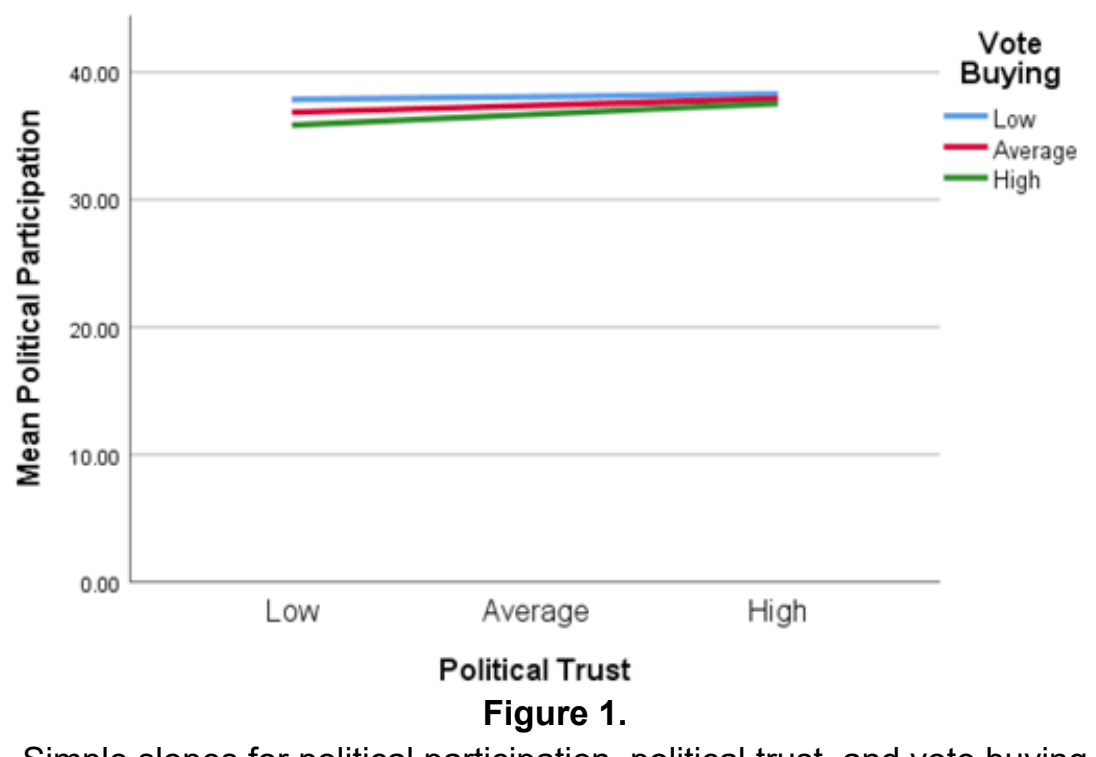

Simple slopes for political participation, political trust, and vote buying

According to the partial regression test, vote-buying reduces the level of political participation; however, in the Moderated Regression Analysis (MRA) and Andrew Hayes tests, vote-buying can strengthen political trust's influence on political participation. It proposes that one of the main objectives of vote-buying is to earn voters' trust in order for them to give their votes to the party in question as a part of political participation. In social exchange theory, the rules about exchange usually involve reciprocal relationships or repayment in the form of actions in response to the acting response (Cropanzano \& Mitchell 2005). It can be illustrated as wrapping something negative behind a positive mask, in the sense of vote-buying as a vote-buying prize. Suryanto et al. 2012 explained that rewards are divided into two types; directly and through associations. The rewards are usually given 
directly by the candidates or through the campaign team. One of the pillars in democratic countries is the involvement of citizens in the general elections. In the modern analysis, political participation is an important issue, and it has been extensively studied, especially in developing countries (Budiardjo 2008). The results of this study indicate that the level of college students' political participation $(51.4 \%)$ is still low. It needs to be further improved. The voices of beginner voters, especially college students, have a high level of potential in elections as they can also act as pioneers, agents of change, and on the frontlines in the process of nation-building. Therefore, college students must be smart when using their votes and participating in keeping the electoral process honest, fair, direct, public, free, and confidential, it will generate a leader who can be the hope of the community.

This study only generalizes the political participation of college students in Surabaya. The researcher chose not to reduce the number of respondents based explicitly on the university. The data collection of the respondents included five universities in Surabaya, East Java Province, Indonesia. The respondents' characteristics studied by the researchers were age, education, and gender.

\section{Conclusion}

It can be concluded that political trust positively and significantly influences college students' political participation in the general elections. It is noted that high political confidence will increase the level of political participation and vice versa. Vote-buying significantly harms the political participation of college students in the general elections. High vote-buying will reduce the level of political participation. If the level of political participation is high, then the rate of vote-buying will below. Political trust and vote-buying simultaneously have a significant influence on political participation. Vote buying has a significant moderating effect (quasi-moderator) by strengthening political trust's influence on college students' political participation in the general elections.

\section{References}

Akhrani LA (2016) Model partisipasi politik warga Jawa Timur ditinjau dari kesadaran politik, kepercayaan politik, orientasi nilai sosial, dan sikap politik. Dissertation, Airlangga University, Surabaya.

Badan Pusat Statistik (2010) Penduduk menurut kelompok umur dan jenis kelamin. [Accessed 20 September 2017]. https://sp2010.bps.go.id/index.php/site/tabel?searchtabel=Penduduk $+\mathrm{M}$ enurut $+\% 20$ Kelompok + Umur + dan + Jenis + Kelamin\&tid=336\&search\%20wilayah $=$ Indon esia\&wid=0000000000\%20\&lang=id.

Berita Satu (2013) KPU Ajak Mahasiswa Tekan Golput, 18 February. [Accessed 19 September 2017]. https://www.beritasatu.com/nasional/97436/kpu-ajak-mahasiswa-tekan-golput.

Bratton M (2008) Vote buying and violence in Nigerian election campaigns. Electoral Studies 27 (4):621-632. https://doi.org/10.1016/j.electstud.2008.04.013.

Budiardjo M (2008) Dasar-Dasar Ilmu Politik. Jakarta: Gramedia.

Carter L \& Campbell R (2011) The impact of trust and relative advantage on internet voting diffusion. Journal of Theoritical and Applied Electronic Commerce Research 6 (3):28-42. https://doi. org/10.4067/S0718-18762011000300004.

Cholisin \& Nasiwan (2012) Dasar-Dasar Ilmu Politik. Yogyakarta: Penerbit Ombak.

Cottam M, Dietz UB, Mastors EM, \& Preston T (2012) Pengantar Psikologi Politik (trans). Jakarta: Rajagrafindo Perkasa.

Cropanzano R \& Mitchell MS (2005) Social exchange theory: An interdisciplinary review. Journal of Management 31 (6):874-900. https://doi.org/10.1177/0149206305279602.

Dermody J \& Scullion R (2008) Delusion of grandeur? Marketing's contribution to "meaningful" westren political consumption. European Journal of Marketing 35 (9):1085-1098. https:// doi.org/10.1108/EUM0000000005960.

Dermody J, Hanmer LS, \& Scullion R (2010) Young people and voting behavior: Alienated youth and (or) an interested and critical citizenry. European Journal of Marketing 44 (3/4):421-435. https://doi.org/10.1108/03090561011020507. 
Detik News (2014) Ikut aksi di HI, ini alasan Mahasiswa ITB dan Unpad dukung Prabowo-Hatta, 5 July. [Accssed 21 September 2017]. https://news.detik.com/berita/d-2628777/ikut-aksi-dihi-ini-alasan-mahasiswa-itb-dan-unpad-dukung-prabowo-hatta.

El Sahn Z, El Sahn F, \& Tantawi P (2013) An examination of the factors affecting voters' intention to participate in the presidential elections in Egypt. The Business Review 12 (1).

Gaffar A (1998) Merangsang Partisipasi Politik Rakyat dalam Demetologisasi Politik Indonesia. Jakarta: Pustaka Cidesindo.

Goeddeke FX (2004) Organizational trust as a mediator of individual union voting intentions in faculty union certification elections. Dissertation, Florida University, Florida.

Grönlund K \& Setälä M (2007) Political trust, satisfaction and voter turnout. Comparative European Politics 5 (4):400-422. https://doi.org/10.1057/palgrave.cep.6110113.

Habibi Y (2014) Jaringan Mahasiswa Lampung dukung Prabowo-Hatta, Republika, 12 May. [Accessed 21 September 2017]. https://www.republika.co.id/berita/pemilu/menuju-ri-1/14/ 05/12/n5f9mt-jaringan-mahasiswa-lampung-dukung-prabowohatta.

Handaningrum R \& Rini RAP (2014) Persepsi terhadap kualitas calon legislatif (caleg), dan kepercayaan politik (political trust) dengan partisipasi politik. Persona Jurnal Psikologi Indonesia 3 (3):223-236. https://doi.org/10.30996/persona.v3i03.1578.

Kana NL (2001) Strategi pengelolaan persaingan politik elit desa di wilayah Kecamatan Suruh: Kasus pemilihan kepala desa. Jurnal Renai 1 (2):5-25.

Komisi Pemilihan Umum (2014) Praktek politik uang pada pemilu legislatif 2014: Studi kasus di Kabupaten Bandung Barat. Bandung: KPU.

Komisi Pemilihan Umum (2015) Pengaruh politik uang terhadap partisipasi pemilih dalam pemilu di Kabupaten Tapanuli Utara. Kabupaten Tapanuli Utara: KPU.

Lewicki RJ \& Bunker BB (1995) Trust in Relationship: A Model of Development and Decline. In: Bunker BB \& Rubin JZ (ed). Conflict, Cooperation, and Justice: Essays Inspired by the Work of Morton Deutsch Conflict, Cooperation, and Justice. San Francisco, United State: Jossey-Bass.

Masturah AN (2014) Jenis kelamin sebagai moderator hubungan keterpercayaan kandidat presiden dengan partisipasi politik pemilih pemula. Thesis, Universitas Gadjah Mada, Yogyakarta.

Matulessy A \& Samsul (2013) Political efficac, political trust and collective self esteem dengan partisipasi dalam gerakan mahasiswa. Jurnal Penelitian Psikologi 4 (1):84-106.

Mayer RC, Davis JH, \& Schoorman FD (1995) An integrative model of organizational trust. Academy of Management Review 20 (3):709-734. https://doi.org/10.5465/amr.1995.9508080335.

Misztal BA (2001) Trust and cooperation: The democratic public sphere. Journal of Sociology 37 (4):371-386. https://doi.org/10.1177/144078301128756409.

Muhtadi B (2018) Buying votes in Indonesia: Partisans, personal networks, and winning margins. Dissertation, Australian National University, Canberra.

Nurdin A (2011) Studi perilaku pemilih di Indonesia: Fenomena pemilih rasional-pragmatis. [Accessed 19 September 2017]. https://www.academia.edu/12247359/Studi_Perilaku_ Memilih_di_Indonesia_Fenomena_Pemilih_Rasional_Pragmatis

Nurdin A (2014) Vote buying and voting behavior in Indonesian local elections: A case in Pandeglang district. Global Journal of Political Science and Administration 3 (6):10-19.

Ondercin HL \& Jones-White D (2011) Gender jeopardy: What is the impact of gender differences in political knowledge on political participation? Social Science Quarterly 92 (3):675-694. https://doi.org/10.1111/j.1540-6237.2011.00787.x.

Pangkalan Data Pendidikan Tinggi (2018) Data pelaporan tahun 2016/2017 jumlah mahasiswa perguruan tinggi universitas. [Accessed 19 September 2017]. https://forlap.ristekdikti.go.id/ perguruantinggi/search. 
Putnam RD, Leonardi R, \& Nanetti RY (1993) Making Democracy Work: Civic Traditions in Modern Italy. New Jersey: Princeton University Press.

Putnam RD (1995) Bowling alone: America's declining social capital. Journal of Democracy 6 (1):65-78. https://doi.org/10.1007/978-1-349-62397-6_12.

Putra A, Susanti CD, Yusari I, Silitonga I, Amrie MH, \& Dhakidae D (2014) Politik Pemilih Muda: Partisipasi Politik Anak Muda di Pekanbaru, Jakarta, Cirebon, Palu dan Jayapura. Jakarta: Demos.

Rigger, SE (1994) Machine politics in the New Taiwan: Institutional reform and electoral strategy in the Republic of China on Taiwan. Dissertation, Harvard University, Massachusetts.

Rini RAP, Suryanto S, \& Matulessy A (2016) The influence of private conformity, group self-esteem, fanaticism and obedience toward the aggressiveness of political party partisan. Dissertation, Airlangga University, Surabaya.

Santrock JW (2011) Life Span Development. New York: McGraw-Hill.

Schaffer FC \& Schedler A (2007) What Is Vote Buying? Empirical Evidence. Manila: Ateneo De Manila University Press.

Schiffman L, Thelen ST, \& Sherman E (2010) Interpersonal and political trust: Modeling levels of citizens' trust. European Journal of Marketing 44 (3/4):369-381. https://doi. org/10.1108/03090561011020471.

Schyns P \& Koop C (2010) Political distrust and social capital in Europe and the USA. Social Indicators Research 96 (1):145-167. https://doi.org/10.1007/s11205-009-9471-4.

Sugiyono (2010) Metode Penelitian Kuantitatif, Kualitatif dan R\&D. Bandung: Alfabeta.

Surbakti R (1999) Memahami Ilmu Politik. Jakarta: Gramedia Widiasarana.

Suryanto, Aniputra MGB, Herdiana I, \& Alfian IN (2012) Pengantar Psikologi Sosial. Surabaya: Pusat Penerbitan dan Percetakan Unair.

Tashandra N (2017) Pendaftaran caleg PAN, kader partai lain hingga mahasiswa dipersilakan, Kompas, 12 April. [Accessed 19 September 2017]. https://nasional.kompas.com/read/2017/04/02/1517 5411/pendaftaran.caleg.pan.kader.partai.lain.hingga.mahasiswa.dipersihlakan.

Vicente PC \& Wantchekon L (2009) Clientelism and vote buying: Lessons from field experiments in African elections. Oxford Review of Economic Policy 25 (2):292-305. https://doi. org/10.1093/oxrep/grp018.

Wahyudi H, Fernando T, Ahmad A, Khairani A, Fatimah F, Agung IM, \& Milla MN (2013) Peran kepercayaan politik dan kepuasan demokrasi terhadap partisipasi politik mahasiswa. Jurnal Psikologi 9 (2):94-99.

Yao Y \& Murphy L (2007) Remote electronic voting systems: An exploration of voters' perceptions and intention to use. European Journal of Information Systems 16 (2):106-120. https://doi. org/10.1057/palgrave.ejis.3000672.

Zetra A, Rosyidi B, Yanuar F, \& Umpu CBP (2015) Laporan penelitian partisipasi politik dan politik uang (vote buying) dalam pemilu legislatif 2014 di Kabupaten Pesisir Selatan. Padang: Komisi Pemilihan Umum.

Zhang Q \& Wang E (2010) Local political trust: The antecedents and effects on earthquake victims' choice for allocation of resources. Social Behavior and Personality: An International Journal 38 (7):929-939. https://doi.org/10.2224/sbp.2010.38.7.929. 